\title{
Cardiology
}

\section{Markers of Oxidative Stress in Patients with Coronary Heart Disease}

\author{
Julia A. Kotova, PhD*; Anna A. Zuikova, PhD, ScD; Alexander N. Pashkov, PhD, ScD; \\ Natalia V. Strahova, PhD; Olga N. Krasnorutskaya, PhD \\ Voronezh State Medical University named after N.N. Burdenko \\ Voronezh, the Russian Federation
}

\begin{abstract}
The aim of this research was to study the blood levels of protein oxidation products and superoxide dismutase (SOD) activity and their relationship with lipid profile parameters in patients with coronary heart disease (CHD). In CHD patients, against a background of low SOD activity, the protein carbonyl content (PCC) level was significantly higher than in the control group. In addition, significant correlations were found between the indices of PCC, SOD activity, and lipid profile parameters. The determination of PCC parameters can serve as a good indicator of the severity of atherosclerosis. (International Journal of Biomedicine. 2018;8(2):115-117.)
\end{abstract}

Key Words: oxidative modification of proteins $\bullet$ superoxide dismutase $\bullet$ oxidative stress $\bullet$ coronary heart disease

\section{Abbreviations}

CCSA classification, Canadian Cardiovascular Society angina classification; CHD, coronary heart disease; OS, oxidative stress; OMP, oxidative modification of proteins; PCC, protein carbonyl content; SOD, superoxide dismutase.

\section{Introduction}

Coronary heart disease (CHD), also known as coronary arteriosclerosis, is one of the leading causes of mortality in Russia. ${ }^{(1,2)}$ Lipid abnormality is one of the major risk factors for atherosclerosis. Immune and inflammatory mediators have a complex role in the initiation and progression of atherosclerosis. ${ }^{(3,4)}$ Chronic inflammation is recognized as a major driving force in atherogenesis. ${ }^{(5)}$ The sites where atherosclerotic plaque develops in the arterial wall are characterized by cholesterol accumulation and infiltration of peripheral blood monocytes, which gradually differentiate into macrophages. Once activated, the monocytes and macrophages secrete a myriad of cytokines that promote inflammation in the arterial wall. ${ }^{(6-8)}$ In $\mathrm{CHD}$, the negative role of reactive oxygen species and a decrease in the level of SOD - the key enzyme of the antioxidant system-has been demonstrated by a number of researchers. ${ }^{(9)}$ The imbalance between pro-

*Corresponding author: Julia A. Kotova, PhD. Voronezh State Medical University named after N.N. Burdenko. Voronezh, the Russian Federation.E-mail: kotova u@inbox.ru oxidants and antioxidants lead to OS, eventually resulting in damage to macromolecules (DNA, RNA, cholesterol, lipids, carbohydrates, and proteins), and the oxidation of these macromolecules produces various end products that can be measured to assess oxidative stress (OS) in vivo. ${ }^{(10,11)}$ Proteins are the molecules most susceptible to oxidative damage in cells because they are often catalysts rather than stoichiometric mediators; hence, the effect of damage to one molecule is greater than stoichiometric. ${ }^{(12)}$ Oxidation of plasma proteins may be discernible as an increased content of carbonyl (aldehyde or ketone) groups on the proteins.

The aim of this research was to study the blood levels of protein oxidation products and SOD activity and their relationship with lipid profile parameters in CHD patients.

\section{Materials and Methods}

We examined 93 patients (43 women and 50 men, mean age of $65.6 \pm 12.0$ ) with cardiovascular disease. Group 1 included 66 patients with stable angina, according to CCSA classification: CCSA class I was determined in 2(3\%) patients, CCSA class II - in 7(10.6\%) patients, and CCSA class III - 
in $57(86.4 \%)$ patients. Distribution of patients according to sex and age was as follows: CCSA class I was determined in $2(100 \%)$ women, mean age $76.0 \pm 1.4$ years; CCSA class II - in $5(71.4 \%)$ women and $2(28.6 \%)$ men, mean age of $67.0 \pm 12.7$ years; CCSA class III - in 25(43.9\%) women and 32(56.1\%) men, mean age of $67.2 \pm 10.9$ years. The duration of coronary heart disease did not differ among groups and was 13.4 \pm 7.9 years.

Group 2 included 27 patients (16 men and 11 women, mean age of $58.7 \pm 14.8$ years) with arterial hypertension Grade 1,2 and 3 (ESH/ESC, 2013). The control group consisted of 29 apparently healthy people.

All patients underwent the following examinations: assessment of traditional risk factors (high blood pressure, smoking, body mass index, diabetes), physical examination, clinical and biochemical laboratory methods, 12-lead ECG, echocardiography; Holter ECG monitoring; treadmill test; coronary angiography (if necessary). Blood samples were obtained in the morning after a $12 \mathrm{~h}$ overnight fast. Total cholesterol (TC), low-density lipoprotein cholesterol (LDL-C), high-density lipoprotein cholesterol (HDL-C), triglycerides (TG), ALT, AST, CFK, apolipoprotein A (ApoA), apolipoprotein B (ApoB), high-sensitivity $\mathrm{C}$-reactive protein (hsCRP), fibrinogen, ESR, WBC were determined in plasma using "Daytona» analyzer (RANDOX, Ireland).

PCC is the most widely used marker of OMP. Carbonyl groups formed from oxidation with 2.4-dinitrophenylhydrazine (DNPH) were estimated using the methods by Levine et al. ${ }^{(13)}$ with modifications by Dubinina et al. ${ }^{(14)}$ The assay is based on the spectrophotometric detection of the reaction between DNPH with protein carbonyl to form protein hydrazone. The optical density of 2,4-dinitrophenylhydrazones derivates was recorded on an SF-36 spectrophotometer. The optical density of aldehyde- and ketone derivatives of a neutral character was recorded at $356 \mathrm{~nm}$ and $370 \mathrm{~nm}$, respectively (ADPHn and KDPHn). The optical density of aldehyde- and ketone derivatives of a basic character was recorded at $430 \mathrm{~nm}$ and $530 \mathrm{~nm}$, respectively (ADPHb and KDPHb). The SOD activity was determined by the spectrophotometric method.

The study was approved by the Voronezh State Medical University Ethics Committee. Written informed consent was obtained from all patients.

Statistical analysis was performed using statistical software package SPSS version 20.0 (SPSS Inc, Chicago, IL).Analysis of the distribution of values obtained was performed using the Kolmogorov-Smirnov test. Quantitative parameters are presented as Median $(\mathrm{Me})$ and $25^{\text {th }}$ and $75^{\text {th }}$ percentiles as Inter Quartile Range (IQR). The Kruskal-Wallis $\mathrm{H}$ test was used to compare medians among 3 comparison groups. Spearman's correlation coefficient $\left(\mathrm{r}_{\mathrm{s}}\right)$ was used to determine the strength and direction of association between two variables. A probability value of $P<0.05$ was considered statistically significant.

\section{Results and Discussion}

In CHD patients, the levels of ADPHn, KDPHn, $\mathrm{ADPHb}$ and $\mathrm{KDPHb}$ were greater by 5.3, 5.6, 5.5, and 9.7 times, respectively, than in the control group $(P=0.000)$. In patients with hypertension, the levels of ADPHn, KDPHn, ADPHb and $\mathrm{KDPHb}$ were greater by $3.8,3.1,3.2$, and 4.2 times, respectively, than in the control group $(P=0.000)$ (Table 1$)$.

Table 1.

Parameters of oxidative modification of proteins in study groups

\begin{tabular}{|l|c|c|c|c|}
\hline Study groups & $\begin{array}{c}\text { ADPHn } \\
(\mathrm{IU} / \mathrm{mg})\end{array}$ & $\begin{array}{c}\mathrm{KDPHn} \\
(\mathrm{IU} / \mathrm{mg})\end{array}$ & $\begin{array}{c}\text { ADPHb } \\
(\mathrm{IU} / \mathrm{mg})\end{array}$ & $\begin{array}{c}\mathrm{KDPHb} \\
(\mathrm{IU} / \mathrm{mg})\end{array}$ \\
\hline Group 1 & $\begin{array}{c}26.1 \\
{[23.7 ; 29.2]}\end{array}$ & $\begin{array}{c}22.6 \\
{[20.2 ; 26.4]}\end{array}$ & $\begin{array}{c}10.9 \\
{[10.3 ; 13.0]}\end{array}$ & $\begin{array}{c}8.8 \\
{[8.2 ; 10.2]}\end{array}$ \\
\hline Group 2 & $\begin{array}{c}18.7 \\
{[16.3 ; 21.2]}\end{array}$ & $\begin{array}{c}12.5 \\
{[11.3 ; 17.8]}\end{array}$ & $\begin{array}{c}6.4 \\
{[5.3 ; 7.8]}\end{array}$ & $\begin{array}{c}3.8 \\
{[3.3 ; 4.8]}\end{array}$ \\
\hline Control group & 4.9 & 4.0 & 2.0 & 0.9 \\
{$[4.2 ; 5.6]^{*}$} & {$[3.2 ; 5.2]^{*}$} & {$[1.7 ; 2.6]^{*}$} & {$[0.6 ; 1.2]^{*}$} \\
\hline
\end{tabular}

$*_{-} P<0.001$

A number of studies have also demonstrated an increase in the OMP level in CHD patients compared to healthy people. ${ }^{(15)}$ A marked increase in products of a neutral nature may be due to an imbalance in trace elements. ${ }^{(16)}$ Products of the basic type are formed with imbalances in the equilibrium between prooxidants/antioxidants status in cellular systems. All revealed changes indicate the severity of free radical oxidation in the groups of patients. ${ }^{(9)}$

SOD activity in studied groups are presented in Figure 1. The highest SOD activity was found in the control group. In Group 2, SOD activity was lower than in the control group, but higher than in Group 1. Statistically significant correlations were found between the blood levels of TC and SOD activity $\left(\mathrm{r}_{\mathrm{s}}=-0.384, P=0.000\right)$ and ADPHn $\left(\mathrm{r}_{\mathrm{s}}=0.347, P=0.000\right)$. The blood LDL-C level correlated with SOD activity $\left(\mathrm{r}_{\mathrm{s}}=-0.395\right.$, $P=0.001)$, ADPHn $\left(\mathrm{r}_{\mathrm{s}}=0.409, P=0.000\right)$, and KDPHb $\left(\mathrm{r}_{\mathrm{s}}\right.$ $=0.389, P=0.000)$. The data obtained are consistent with the results of studies by other authors. ${ }^{(11)}$

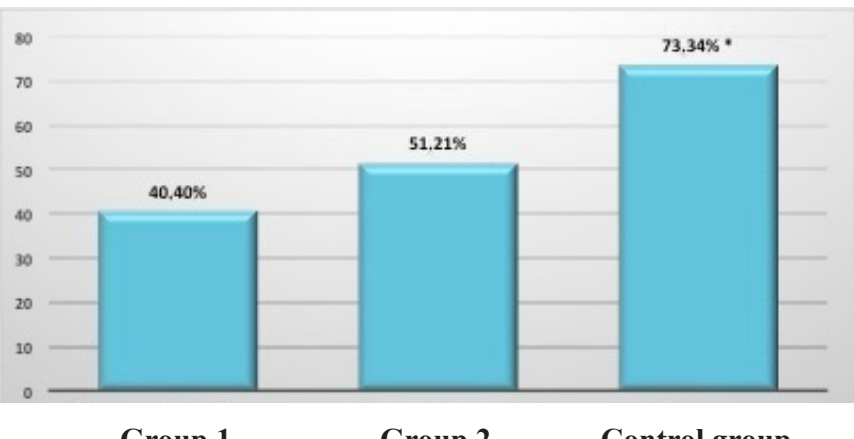

Group 1

Group 2

Control group

Fig. 1. The level of SOD activity in the study groups $*_{-} P<0.05$ (The Kruskal-Wallis H test)

\section{Conclusion}

In CHD patients, against a background of low SOD activity, the PCC level was significantly higher than in the control group. In addition, significant correlations were found 
between the indices of PCC, SOD activity, and lipid profile parameters. The determination of PCC parameters can serve as a good indicator of the severity of atherosclerosis.

\section{Competing interests} interests.

The authors declare that they have no competing

\section{Sources of Funding}

This work was partially supported by the Council on Grants of the President of the Russian Federation for State Support of Young Scientists and Leading Scientific Schools (Grant MK-552.2018.7).

\section{References}

1. Rudakova DM, Veselovskaya NG, Chumakova CA. [Coronary Atherosclerosis in Men with Metabolic Syndrome: Risk Factors and the Role of Myocardial Cytoprotective Agents]. Doctor.Ru. 2017;10(139):15-20. [Article in Russian]. 2. Marzilli M, Merz CNB, Boden WE, Bonow RO, Capozza PG, Chilian WM, et al. Obstructive coronary atherosclerosis and ischemic heart disease: an elusive link! J Am Coll Cardiol. 2012;60(11):951-6. doi: 10.1016/j.jacc.2012.02.082.

3. Musthafa QA, Abdul Shukor MF, Ismail NAS, Mohd Ghazi A, Mohd Ali R, M Nor IF, et al. Oxidative status and reduced glutathione levels in premature coronary artery disease and coronary artery disease. Free Radic Res. 2017;51(9-10):787798. doi: 10.1080/10715762.2017.1379602.

4. Mahalakshmi A, Kurian GA. Evaluating the impact of diabetes and diabetic cardiomyopathy rat heart on the outcome of ischemia-reperfusion associated oxidative stress. Free Radic Biol Med. 2018;118:35-43. doi: 10.1016/j.freeradbiomed.2018.02.021. 5. Galkina E, Ley K. Immune and inflammatory mechanisms of atherosclerosis. Annu Rev Immunol. 2009;27:165-97. doi: 10.1146/annurev.immunol.021908.132620.

6. Tedgui A, MallatZ. Cytokines in atherosclerosis: pathogenic and regulatory pathways. Physiol Rev. 2006;86(2):515-81.

7. Rajamäki K, Lappalainen J, Oörni K, Välimäki E, Matikainen S, Kovanen PT, Eklund KK. Cholesterol crystals activate the NLRP3 inflammasome in human macrophages: a novel link between cholesterol metabolism and inflammation. PLoS One. 2010;5(7):e11765. doi: 10.1371/journal.pone.0011765.

8. Lankin VZ. [The role of free radicals in atherogenesis]. Kardiologicheskij Vestnik. 2009;1:62-63.[Article in Russian]. 9. Zanozina OV, Borovkov NN, Sherbatyuk TG. [Oxidized Modified Proteins in the Atherosclerosis Genesis at a Diabetes Mellitus of the 2nd Type]. Sovremennye tehnologii v medicine. 2009;2:72-75. [Article in Russian].

10. Celi P, Gabai G. Oxidant/Antioxidant Balance in Animal Nutrition and Health: The Role of Protein Oxidation.Front Vet Sci. 2015;2:48. doi: 10.3389/fvets.2015.00048. eCollection 2015 11. Tikhomirova YuR, Kontorshchikova KN. [Indicators of lipid metabolism and oxidative modification of proteins in metabolic disorders. Bioradicals and Antioxidants. 2015;2(1): 62-66. [Article in Russian].

12. Dalle-Donne I, Scaloni A, Giustarini D, Cavarra E, Tell $\mathrm{G}$, Lungarella $\mathrm{G}$, et al. Proteins as biomarkers of oxidative/ nitrosative stress in diseases: the contribution of redox proteomics. Mass Spectrom Rev. 2005;24(1):55-99.

13. Levine RL, Garland D, Oliver CN, Amici A, Climent I, LenzAG, et al. Determination of carbonyl content in oxidatively modified proteins. Methods Enzymol. 1990;186:464-478.

14. Dubinina EE, Burmistrov SO, Khodov DA, Porotov IG. [Oxidative modification of human serum proteins. A method of determining it].Vopr Med Khim. 1995;41(1):24-6. [Article in Russian].

15. Bykova AA, Azizova OA, Dumikyan ASh, Shvachko AG, Sergienko VI, Syrkin AL. [Oxidative modification of fibrinogen in patients with ischemic heart disease]. Russian Journal of Cardiology. 2015;(4 Sippl 1):24. [Article in Russian].

16. Fomina MA, Abalenikhina YuV. Oxidative modification of tissue proteins by changing the synthesis of nitric oxide. Moscow: "GEOTAR-Media"; 2018. [in Russian]. 